\title{
WORK-LIFE BALANCE AND JOB STRESS OF EMPLOYEES OF A LONE AGRICULTURAL COLLEGE IN BULACAN, PHILIPPINES
}

\author{
Imee De Guzman Esguerra \\ Bulacan Agricultural State College, Philippines \\ meeic.knight99@gmail.com
}

\begin{abstract}
This study utilized the descriptive correlational research method wherein a modified survey questionnaire was used to gather data from 107 employees of BASC. Frequency count, percentage, Pearson's $r$ Correlation Coefficient was used in data analysis. The majority of the respondents are female, married, with below five-year work experience and rank and file employees. The total work-life balance of the majority of the respondents was out of balance as more than half of them felt that their work-life balance in terms of work and career, friends and family, fitness and health, fun/recreation and money is on the edge while the rest is out of balance. Only in terms of romance and significant other did they believe that they have a right balance work-life situation. Among the demographic profile, age, educational attainment, and work-life balance in all the seven areas were found to be significantly correlated to the job stress of the employees in BASC.
\end{abstract}

Keywords: Work-Life Balance; Job Stress; Human Resource Management

\section{INTRODUCTION}

Human resources are the most valuable and unique assets of an organization (Kanthisree \& Sarada, 2013). Employees play a key role in any business formation and therefore there is a need to provide an enabling environment at all levels to attain the stated objectives and goals of the organization (Abioro et al., 2018). However, increasing demands between work and home are becoming a major concern for employees in recent years (Abioro et al., 2018). The decline of the traditional family, an increase in dual-career couples, and a rise in the number of single parents mean that employees are juggling more responsibilities outside work (Lazăr et al., 2010). Balance in work and family life is an emerging challenge for both employees and employers (Meenakshi et al., 2013). The quality relationship between paid work and unpaid responsibilities is critical for success (Lazăr et al., 2010).

Work-life balance is about creating and maintaining supportive and healthy work environments, which will enable employees to have balance between work and personal responsibilities and thus strengthen employee loyalty and productivity (Dhas, 2015). Work-life balance programs have been demonstrated to have an impact on employees in terms of recruitment, retention/turnover, commitment and satisfaction, reduce absenteeism, job stress levels, work-life conflict and accident 
rates; and increased productivity (Dhas, 2015); increased job satisfaction and enhanced control over their work schedule (Lazăr et al., 2010).

An employee is said to derive pleasure and self-fulfillment at home and work when there is the lowest role conflict. The practice of work-life balance approaches is to enhance stability between the hassles of the occupation and the robust management of life outside the work station and flexible work environment (Abioro et al., 2018). Providing quality of life for an employee at the same time retaining their productivity levels in the workplace is the main focus for work-life balance (Odunayo et al., 2020).

However, work-life balance conflicts are often associated with the gendered division of labor at home. Notably, women are more vulnerable to experience worklife conflict as they are required to do longer working hours among the labor force (Azeem \& Akhtar, 2014). According to a 2007 study by Duxbury and Higgins (as cited by Dhas, 2015), women report higher levels of work-family conflict than do men because they devote more hours per week to non-work activities such as childcare, elder care and are more likely to have primary responsibility for unpaid labor such as domestic work.

Kluczyk (2013) found that the main causes of work-family conflicts were excessive working hours and inflexibility of work schedules. Long work hours and highly stressful jobs not only hamper employees' ability to harmonize work and family life but also are associated with health risks, such as increased smoking and alcohol consumption, weight gain and depression (Dhas, 2015). Hence, the health domain should also be considered in addition to the family domain when investigating the work-life balance (Gragnano et al., 2020).

In the case of the organization, work-life conflict also has significant business costs associated with lack of engagement, absenteeism, turnover rates, low productivity and creativity or poor retention levels (Kanthisree \& Sarada, 2013; Lazăr et al., 2010), lower satisfaction with work and commitment towards employers, and higher degrees of distress, concentration problems, sleeping problems, unhappiness, and lack of confidence (Kluczyk, 2013).

Unfortunately, management has yet to recognize that unbalanced workfamily life caused by increased work demands leads to higher levels of stress which results in family-work conflicts that have a negative impact not only on the wellbeing of employees, but also on other life and social demand (Odunayo et al., 2020).

Oludayo (2018) suggested that management should be more accommodating to worker's needs. Abioro et al. (2018) also conclude that for Universities to achieve high level of performance, there is a need to pay more attention to the work-life balance of its workforce across all levels.

Bulacan Agricultural State College (BASC) is a lone agricultural Higher Education Institution (HEI) in Bulacan, Philippines. As an HEI, it is mandated to perform four-fold functions of instruction, research, extension and production, thus requires performance of multiple workload to both its teaching and non-teaching employees. Workplace stress can be beneficial to employees as it energizes and motivates the employees at the workplace. However, if not appropriately managed, problems might arise such as employee turn-overs, absenteeism, low productivity, unhealthy employees (both physical and mental state) and lack of engagement (Kanthisree \& Sarada, 2013; Lazăr et al., 2010). 
Hence, this study was conducted to determine the relationship between the work-life balance of BASC employees and their level of job stress. Specifically, the study described the demographic profile, status of work-life balance and level of job stress of employees. It also explained the relationship of profile factors and work-life balance of the employees in BASC with the level of stress that they experienced in their job. No study so far has been conducted in BASC on employeerelated concerns of its employees. The findings of this study served as eye-opener not only to the administrative personnel, but also to the respondents, themselves as they were able to do a self-check of the status of their work-life balance and got reminded of its importance to their lives.

\section{METHODOLOGY}

This study utilized the descriptive correlational method of research. The dependent variable that is the primary interest of this research is job stress. There are two main independent variables used in an effort to explain the variance in employees' perception of job stress. First independent variable is the profile factor, which includes gender, age, civil status, educational attainment, work experience, job level/position. The second independent variable is work-life balance in terms of work and career, friends and family, personal and spiritual growth, romance/significant other, fitness/health, fun/recreation and money.

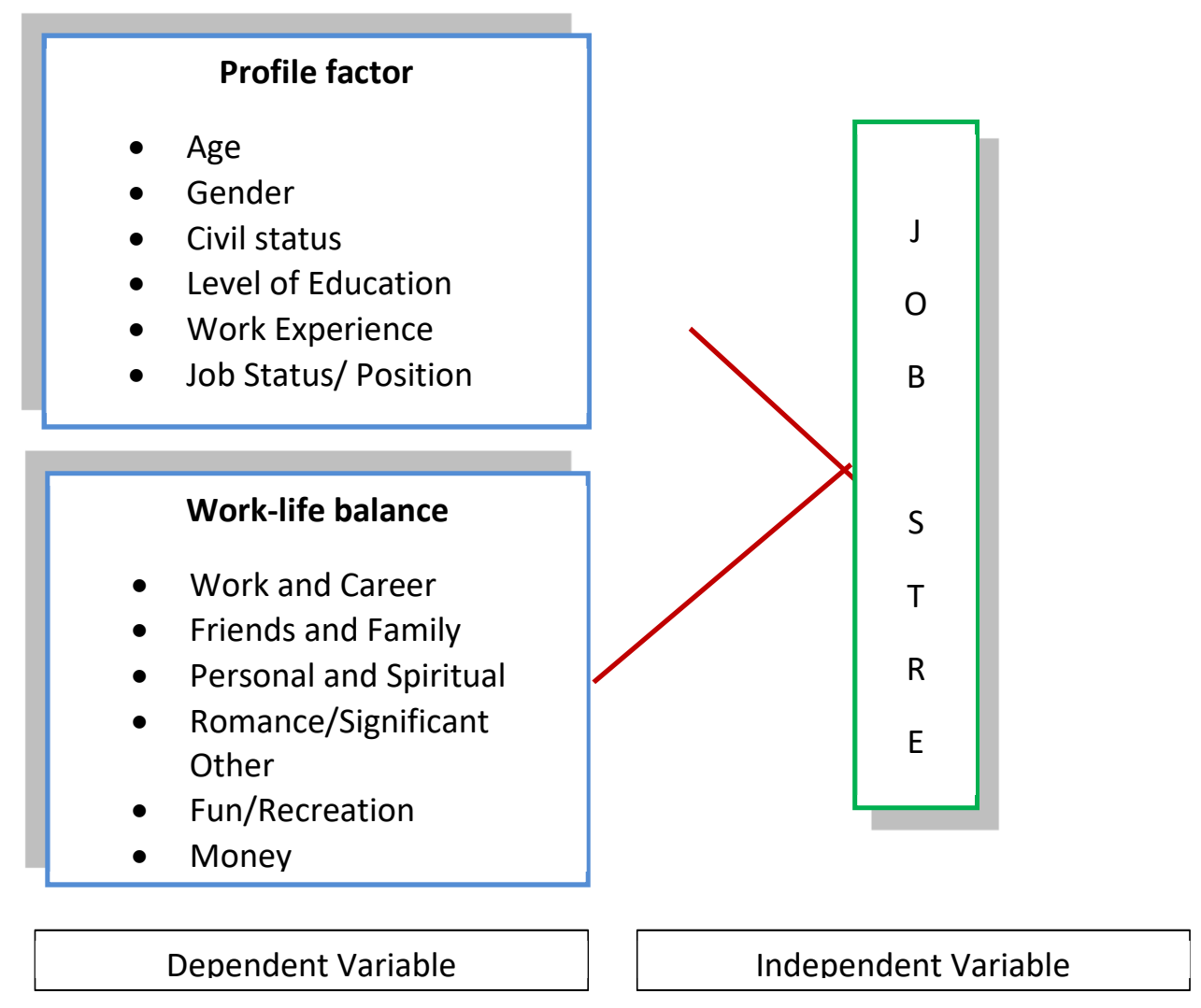

Figure 1 Schematic diagram of the Conceptual Framework 
This study explained the relationship between the independent variables profile factors and work-life balance with the dependent variable which is job stress using the quantitative approach method.

The population of the study comprised the employees of Bulacan Agricultural State College (BASC). Total sampling technique was used to determine the worklife balance status of everyone. However, out of the total 178 copies of the questionnaires distributed, only 119 questionnaires were recovered because some of the respondents lost their questionnaires while others could not answer it because of the too busy schedule. From the 119 retrieved questionnaires, 12 were not properly filled out or are not viable for the completion of the research that is why these were eliminated, thus leaving only a total of 107 valid responses that were analyzed and interpreted.

The measuring instrument used in this study was structured in a way that the data on individuals' perceptions were gathered. The two-page questionnaire consisted of three sections. Section 1 included the profile factors, while section 2 consisted of the statements for each area of work-life balance and the last part describes the level of stress perceived by the employees in their job. The profile section of the questionnaire required the respondents to answer the following personal information:

- Gender

- Age

- Civil status

- Level of Education

- Work Experience

- Job Level/Position

The aim of including the profile information in the questionnaire was to determine whether profile factor variables influenced another variable, job stress.

In this study, the work-life balance of the respondents was measured using the work-life balance quiz of Savvy Life Skills, LLC wherein the quiz is structured on seven areas of life namely: work and career, friends and family, personal and spiritual growth, romance and significant other, fitness/health, fun/recreation and money. The questionnaire provided four statements for each area which were then identified by the respondents whether true or false, by encircling $\mathrm{T}$ or $\mathrm{F}$. Each true response is an indication that some part of their life is not in balance. The higher the score, the more imbalance their life is. Only the true response was counted which was then interpreted using the following scale:

$0 \quad$ - well balanced

1-2 - on the edge

3-4 - out of balance

However, in the case of the respondents' total work-life balance, the scale below was used in the interpretation.

0-4 - well balance 
5-7 - on the edge

$7+\quad$ - out of balance

On the other hand, the level of job stress of employees was measured using the 8-item questionnaire of Martin Company wherein the respondents were asked to rate their experience in their job based on the statements provided from the scale of 1 to 5 with the following equivalent verbal interpretation:

$1=$ Never, $2=$ Rarely, $3=$ Sometimes, $4=$ Often, $5=$ Very Often

The reversed score is applied for letters F, G and $\mathrm{H}$ because the statements are expressed positively.

Likert-type scale was utilized in this questionnaire. This was designed to get information about a specific attitude or perception. Each respondent was presented with five (5) alternative responses for each statement. The final score for each dimension was obtained by calculating the weighted mean score for each dimension. The numbers of the scale are defined below:

$$
\begin{array}{ll}
1-1.49 & - \text { No Stress } \\
1.5-2.49 .1 & - \text { Little Stress } \\
2.50-3.49 & - \text { Some Stress } \\
3.50-4.49 & - \text { Quite a bit of Stress } \\
4.50-5.0 & - \text { A great deal of Stress }
\end{array}
$$

The survey process was structured in a way to encourage honesty. If participants in a survey remain anonymous, they are likely to provide honest responses that is why names are not asked in the survey.

Data gathered were analyzed using frequency, percentage, Pearson's Correlation Coefficient and applied a two tailed test or non-directional hypothesis to scale the result of job stress in relation to profile factors and work-life balance of the employees.

\section{RESULTS AND DISCUSSION}

\section{Results}

\section{Profile of Employees}

Majority of the respondents are female (70\%), belonging to the younger age bracket of 25-29, (the oldest respondent is 63 years old while the youngest is 20), married (64.49\%), a little more than half are Bachelor's Degree holders $(50.47 \%)$ with mean length of service of 13.7 years and were rank and file employees $(87.85 \%)$.

\section{Status of Work-Life Balance of Employees}

Work and Career. More than half of the respondents (59.81\%) felt that their work-life balance in terms of work and career was on the edge which means partly 
imbalance, $27.10 \%$ of them sensed that they are out of balance while the remaining $13.08 \%$ felt otherwise.

Friends and Family. More than half of the respondents $(51.40 \%)$ thought that their work-life balance in terms of friends and family was on the edge. There is a slight difference between the number of respondents who felt that their worklife balance is actually out of balance $(25.23 \%)$ and those who believed that their work-life condition was well balance $(23.36 \%)$.

Personal and Spiritual Growth. Almost half of the respondents (50.47\%) perceived that their work-life balance in terms of personal and spiritual growth was on the edge. However, $23 \%$ of the respondents still believed that their work-life balance in terms of personal and spiritual growth was well-balanced, contrary to the remaining $24.30 \%$ who felt that theirs is actually out of balance.

Romance and Significant Other. Majority of the respondents (62.62\%) believed that they have a good balance work-life balance in terms of romance and significant other. Conversely, $31.78 \%$ of the respondents thought that their worklife balance is on the edge while the remaining $5.61 \%$ felt that theirs is out of balance which means that they do not have time or energy to go into a relationship.

Fitness/Health. More than half of the respondents (53.27\%) felt that their work-life balance in terms of fitness and health is on the edge with 53.27 while $28.97 \%$ perceived that their work-life balance is actually out of balance. On the contrary, $17.76 \%$ believed that they have a well-balance work-life in terms of fitness/health.

Fun/Recreation. Almost half of the respondents (46.73\%) perceived that their work-life balance in terms of fun/recreation is on the edge while $46.73 \%$ felt that their work-life is out of balance. On the other hand, $25.23 \%$ felt otherwise who believed that their work-life balance in terms of fun and recreation is well balance.

Money. A little greater than half of the respondents (55.14\%) felt that their work-life balance in terms of money is on the edge while $31.78 \%$ of them perceived that their work-life status as out of balance.

Total Work-life Balance. Majority of the respondents (72.90\%) found their total work-life balance to be out of balance; $15.89 \%$ perceived that they were on the edge of losing balance; while only $11.21 \%$ felt that their work-life balance was totally well balanced in all the seven areas of life.

Table 1. Distribution of Employees by total Work-life Balance

\begin{tabular}{lll}
\hline Level & Frequency & Percent \\
\hline $0-4$ (well-balance) & 12 & 11.21 \\
$5-7$ (on the edge) & 17 & 15.89
\end{tabular}




$\begin{array}{lll}7+(\text { out of balance }) & 78 & 72.90 \\ \text { Total } & 107 & 100.00\end{array}$

\section{Part III Job Stress}

Level of Job Stress. Employees experienced some stress for items A to E which means that the level of stress of employees of BASC was still in moderation while for letters F and G, they felt quite a bit of stress and the last item which is the letter $\mathrm{H}$ gave them stress. The overall weighted mean is 3.06 which means that the respondents experience some stress in their work in totality.

Table 2. Level of Job Stress of Employees

\begin{tabular}{lll}
\hline Items & $\begin{array}{l}\text { Weighted } \\
\text { Mean }\end{array}$ & $\begin{array}{l}\text { Verbal } \\
\text { Description }\end{array}$ \\
\hline $\begin{array}{l}\text { A. Conditions at work are unpleasant or } \\
\text { sometimes even unsafe. }\end{array}$ & 2.52 & Some stress \\
$\begin{array}{l}\text { B. I feel that my job is negatively affecting } \\
\text { my physical or emotional well-being. }\end{array}$ & 2.54 & Some stress \\
$\begin{array}{l}\text { C. I have too much work to do and/or too } \\
\text { many unreasonable deadlines. }\end{array}$ & 2.97 & Some stress \\
$\begin{array}{l}\text { D. I find it difficult to express my opinions } \\
\text { or feelings about my job conditions to my } \\
\text { superiors. }\end{array}$ & 2.73 & Some stress \\
$\begin{array}{l}\text { E. I feel that job pressures interfere with my } \\
\text { family or personal life. }\end{array}$ & 2.8 & \\
$\begin{array}{l}\text { F. I have adequate control or input over my } \\
\text { work duties. }\end{array}$ & 3.66 & Some stress \\
$\begin{array}{l}\text { G. I receive appropriate recognition or } \\
\text { rewards for good performance. }\end{array}$ & 3.09 & Quite a bit of \\
$\begin{array}{l}\text { H. I am able to utilize my skills and talents } \\
\text { to the fullest extent at work. }\end{array}$ & 4.16 & Stress \\
\hline $\begin{array}{l}\text { Composite mean } \\
\text { Quite a bit of }\end{array}$ & Stress \\
\hline
\end{tabular}


Correlation. Table 3 presents the correlation between the profile factors, work-life balance and job stress of employees.

Table 3. Correlation of profile factors, work-life balance and level of job stress of employees

\begin{tabular}{|c|c|c|c|c|}
\hline Variables & $\mathbf{r}$ & Magnitude & Significance & Decision \\
\hline Gender & 0.1034 & low association & not significant & $\begin{array}{l}\text { cannot reject } \\
\text { Ho }\end{array}$ \\
\hline Age & -0.208 & low association & significant & reject Ho \\
\hline $\mathrm{CS}$ & 0.0386 & $\begin{array}{l}\text { negligible } \\
\text { association }\end{array}$ & not significant & $\begin{array}{l}\text { cannot reject } \\
\text { Ho }\end{array}$ \\
\hline Educ & -0.22 & low association & significant & reject Ho \\
\hline $\operatorname{Exp}$ & -0.145 & low association & not significant & $\begin{array}{l}\text { cannot reject } \\
\text { Ho }\end{array}$ \\
\hline Position & -0.097 & $\begin{array}{l}\text { negligible } \\
\text { association }\end{array}$ & not significant & $\begin{array}{l}\text { cannot reject } \\
\text { Ho }\end{array}$ \\
\hline WLB1 & 0.2504 & low association & significant & reject Ho \\
\hline WLB2 & 0.3832 & $\begin{array}{l}\text { moderate } \\
\text { association }\end{array}$ & significant & reject Ho \\
\hline WLB3 & 0.374 & $\begin{array}{l}\text { moderate } \\
\text { association }\end{array}$ & significant & reject Ho \\
\hline WLB4 & 0.1874 & low association & significant & reject Ho \\
\hline WLB5 & 0.4048 & $\begin{array}{l}\text { moderate } \\
\text { association }\end{array}$ & significant & reject Ho \\
\hline WLB6 & 0.4298 & $\begin{array}{l}\text { moderate } \\
\text { association }\end{array}$ & significant & reject Ho \\
\hline WLB7 & 0.1783 & low association & significant & reject Ho \\
\hline WLBT & 0.4786 & $\begin{array}{l}\text { moderate } \\
\text { association }\end{array}$ & significant & reject Ho \\
\hline
\end{tabular}

Among respondents' demographic profile, only age and educational attainment were found to have a significant relationship with job stress.

With $r=-0.208$, the study depicts that there is a low negative significant relationship between age and job stress, therefore, Ho should be rejected. In terms of educational attainment and job stress, with $r=-0.22$, there is a low, negative 
significant relationship between educational attainment and job stress, so Ho should be rejected.

\section{DISCUSSION}

\section{Profile of Employees}

The results indicate that BASC has a young generation of employees serving as its human resources. This young blood can become potential assets of the institution if nourished well through having a work-life balance program for their welfare. Kanthisree \& Sarada (2013) noted that human resources are the most valuable and unique assets of an organization. They play a key role in any business formation and therefore there is a need to provide an enabling environment at all levels to attain the stated objectives and goals of the organization (Abioro et al., 2018).

\section{Status of Work-Life Balance of Employees}

Work and Career. The result can be attributed to why the nature of teachers' work (lesson preparation, checking of papers, exams, etc.) did not end in the school premises but requires extra time at home to finish them all. It seems to reflect the findings of the 2007 School Teachers' Review Body (STRB) work survey which bear witness to the fact that teachers overall have not been benefited from a significant reduction in workload as most of them continue to report working over 50 hours a week (School Teachers' Review Body, 2007).

Friends and Family. Employees perception of their work-life balance status in terms of friends and family as being on edge can be attributed to the reason that due to the call of duty, sometimes they have missed important family events and lose track of their friends. The findings seem to reflect Duxbury and Higgins' conclusion as cited by Lowe (2007b) that role overload increased substantially due to rising work demands, although other forms of work-family conflict had smaller increases.

Personal and Spiritual Growth. Since majority of the respondents are teachers, sometimes they forget to take care of themselves because they are too busy taking care of their students. Likewise, because of their work's rising demands, sometimes they missed attending church gatherings that will further strengthen their spiritual life.

Romance and Significant Other. No matter how busy the respondents are in their work, they still find time to spend with their partners. They still have time to invest in a significant relationship and do not allow problems to go unresolved.

Fitness/Health. Majority of the respondents felt that they are stressed and tired most of the time and do not find time to do exercise even though they knew that they need it thus resulted in sickness and health problems. The distribution seems to reflect the findings of Fatima \& Sahibzada (2012) in their study wherein the increasing demands from work and family were the source of high strain for many teachers, thus resulting in stress-related health problems. 
Fun/Recreation. Respondents claimed that the bulk of teachers' work is why instead of getting out to do fun things, they just chose to stay at home or in school to finish their workloads on time. The result seems to reflect the findings of the 2007 School Teachers' Review Body (STRB) in the UK that lack of work-life balance adversely impacts in all and reduces their chances of good health and their ability to balance workload and other activities, such as learning, sports leisure, and family life.

Money. Majority of the respondents have concerns about an adequate income to meet their needs and do not have a budget that they stick to. Respondents explained that this is because when they worked, they are not receiving overtime pay. As cited by Lowe (2007) workers who are not compensated for overtime are most likely to say that the work-life balance has become harder to achieve over the past few years.

Total Work-life Balance. The result is alarming since majority felt out of balance between work and personal life. Punia \& Kamboj (2013) concluded in their study that work-life balance is important for an individual's psychological wellbeing, for elevated self-esteem, job satisfaction, and overall sense of harmony in life.

\section{Part III Job Stress}

Level of Job Stress. The level of stress of employees of BASC is consistent with the findings of Darmody \& Smyth (2011) in their study wherein they found out that just over one-third of all teachers were satisfied with their job while the rest are dissatisfied. Similarly, Kyriacou \& Chien (2004) found that $26 \%$ of the teachers reported that being a teacher in Taiwan was either very or extremely stressful.

Correlation. The results indicate that the older the employee, the lower is the level of job stress and the younger the employee, the higher is the level of job stress. This can be attributed to the fact that in BASC, younger employees are usually those with contractual status that is why they have no other choice but to accept more workload as compared to older employees who have permanent status. Hence, they are likely to feel more stressed. In addition, the results can also be due to the reason that since older employees are already doing their work for a number of years, they are well familiar with their routine tasks.

Conversely, younger employees are just new in their job so most likely, they are still adjusting in their jobs. Hence, they are likely to experience more stress. This seems to contradict the findings of Darmody \& Smyth (2011) in their study wherein teachers aged in their forties had higher stress levels than other age groups. Stress levels were also higher for principals over 40 years of age.

The study also found that the higher the respondents' educational attainment, the lower is the job stress and vice versa. The result can be attributed to the reason that those who have higher educational attainment are more knowledgeable in doing their work compared to those who have low educational attainment. Thus, they are less stressed in their job. This seems to reflect the findings of Darmody \& Smyth (2011) that stress levels were significantly lower among those principals who have high educational attainment and had previous experience in a similar role in another school as compared to the level of teacher's stress. 
It can be noted that three areas of work-life balance, namely: work and career, romance and significant other and fun/recreation have a low, positive significant relationship to job stress. This means that the higher the work-life imbalance of the employee in the three areas, the higher is the level of their job stress. Moreover, the computation indicated that the remaining four work-life balance areas, including friends and family, personal and spiritual growth, fitness/health and money have a moderate, positive significant relationship to job stress. This implies that the level of work-life imbalance in these four areas has a moderate impact on the employees' level of job stress in their work. With this, the computation revealed that there is a moderate, positive significant relationship between the total work-life balance and job stress of the respondents, thus Ho for all these areas was rejected. Srivastava (2009) found out that there is a positive relationship between conflict and job stress. Graham Lowe (2007a) further expressed that high stress is equated with work-life balance difficulties.

\section{CONCLUSION}

Among the respondents' demographic profile, only age and educational attainment were found to have a significant relationship with the level of job stress. Younger employees and with low educational attainment have higher levels of job stress. Positive significant relationship between the respondents' all areas of worklife balance and job stress was also revealed in the study. Hence, the level of worklife balance of employees is correlated to their level of job stress. Support should be given to the younger employees in pursuing their graduate studies in order to earn higher education degrees which will open more doors for their career growth. Access to both internal and external scholarship grants and other faculty development support can be a good way of encouraging younger employees to improve their educational attainment. Likewise, BASC can also devise a work-life balance program to address work overload such as practicing flexible working, giving employees the freedom to choose the best work schedule suitable to their lifestyle, thus translating to a good work-life balance situation. The study can be replicated using a larger sample size than what was used in this study or they may also take samples from other State Colleges and Universities in order to make the research more generalized and realistic. Future researcher may also include the job status (whether permanent, contractual, part-time, full-time, etc.), the nature and pressure of the job (mental, physical, both mental and physical), organizational climate and quality of work environment as these may also influence the level of job stress of the respondents.

\section{ACKNOWLEDGMENT}

The researcher would like to extend deep gratitude to all respondents to share their time and insights in this study's conduct.

\section{REFERENCES}

Abioro, M. A., Oladejo, D. A., \& Ashogbon, F. O. (2018). Work Life Balance Practices and Employees Productivity in The Nigerian University System. 
Crawford Journal of Business \& Social Sciences, 13(2), 49-59. https://www.researchgate.net/publication/328733295

Azeem, S. A., \& Akhtar, N. (2014). The Influence of work life balance and job satisfaction on organizational commitment of healthcare employees. International Journal of Human Resource Studies, 4(2), 18-24.

Darmody, M., \& Smyth, E. (2011). Job Satisfaction and Occupational Stress among Primary School Teachers and School Principals in Ireland. The Teaching Council and ESRI.

Dhas, B. (2015). A report on the importance of work-life balance. International Journal of Applied Engineering Research. https://www.researchgate.net/publication/282685585

Fatima, N., \& Sahibzada, S. A. (2012). An Empirical Analysis of Factors Affecting Work Life Balance among University Teachers: the case of Pakistan. Journal of International Academic Research. https://www.researchgate.net/publication/278009787_An

Empirical_Analysis_of_Factors_Affecting_Work_Life_Balance_among_Uni versity_Teachers_the_case_of_Pakistan

Gragnano, A., Simbula, S., \& Miglioretti, M. (2020). Work-Life Balance: Weighing the Importance of Work-Family and Work-Health Balance. International Journal of Environmental Research and Public Health. http://www.mdpi.com/1660-4601/17/3/907/s1

Kanthisree, G., \& Sarada, M. D. (2013). Work-life Balance of Employees (A Study on Selected Public and Private Sector Undertakings). Andhra University.

Kluczyk, M. (2013). The Impact of Work-Life Balance on the Wellbeing of Employees in the Private Sector in Ireland. National College of Ireland

Kyriacou, S., \& Chien, P.-Y. (2004). Teacher stress in Taiwanese Primary Schools. Journal of Educational Enquiry, 5(2), 86-104.

Lazăr, I., Osoian, C., \& Ratiu, P. (2010). The Role of Work-Life Balance Practices in Order to Improve Organizational Performance. European Research Studies, 13(1).

Lowe, G. (2007a). Stress. Human Solutions Report 2006 - 07. grahamlowe.ca

Lowe, G. (2007b). Under pressure: Implications of Work-Life Balance and Job Stress. grahamlowe.ca

Meenakshi, S. P., Subrahmanyam, V., \& Ravichandran, K. (2013). he Importance of Work-Life-Balance. IOSR Journal of Business and Management, 14(3), 3135. www.iosrjournals.org

Odunayo, A. O., Fubara, O. K., \& Oluwatosin. (2020). Assessing the Influence of Flexible-Work-Option as a Precursor of Work Life Balance on Employee 
Productivity of Logistics Companies in Rivers State Nigeria. British Journal of Management and Marketing Studies, 3(1), 55-66. www.abjournals.org

Oludayo, O. (2018). Work-Life Balance Initiative as a Predictor of Employees' Behavioural Outcomes. Academy of Strategic Management Journal, 17(1).

Punia, V., \& Kamboj, M. (2013). Quality of Work-life Balance Among Teachers in Higher Education Institutions. Learning Community-An International Journal of Education and Social Development, 4(3), 197-208. https://doi.org/10.5958/j.2231-458X.4.3.010

School Teachers' Review Body. (2007). School Teachers' Review Body sixteenth report. https://www.gov.uk/government/publications/school-teachers-reviewbody-sixteent-report-2007

Srivastava, S. (2009). Organizational Variables and Job Stress: Effect of Moderating Variables, Management \& Change. IILM Institute for Higher Education. 